\title{
PSYCHIATRIC ILLNESS AT GENERAL HOSPITAL CLINICS
}

\author{
Brian Davies, M.D., M.R.C.P., D.P.M., D.C.H. \\ Senior Registrar, The Bethlem Royal Hospital and The Maudsley Hospital, London
}

Patients suffering from a psychiatric illness often present with many bodily complaints. It is not surprising to find, therefore, that these patients are sometimes referred to the general hospital clinics for the investigation of somatic disease. The aim of this paper is to review the subject, describe an investigation at a general hospital clinic and to discuss the various problems raised.

Relatively few investigations have been made into the problems presented by psychiatric patients at the general clinics, though it is a large and important one. Table I shows the reported incidence of psychiatric illness among medical out-patients. The mean is $27.3 \%$. Patients with concurrent organic and psychiatric illness account for another 10 to $40 \%$ of the patients seen in the different surveys.

TABLe I

Previous Reports on Incidence of Psychiatric Illness in 'NON-PSYChiatric' Patients

\begin{tabular}{|c|c|c|c|}
\hline Author & Place & $\begin{array}{c}\text { Num- } \\
\text { ber } \\
\text { of } \\
\text { Patients }\end{array}$ & \begin{tabular}{|} 
Per- \\
centage \\
with \\
Psychi- \\
atric \\
Illness
\end{tabular} \\
\hline $\begin{array}{l}\text { Allan and Kauf- } \\
\text { man (1948) } \\
\text { Buck (1930) } \\
\text { Hamman (1939) } \\
\text { Lewis (1952) } \\
\text { Lewis (1953) } \\
\text { McLean (1932) } \\
\text { Moersch (1932) } \\
\text { Pearson (1938) } \\
\text { Pemberton (1951) } \\
\text { Reynolds (1930) } \\
\text { Roberts and } \\
\text { Norton (1952) }\end{array}$ & $\begin{array}{l}\text { Lahey Clinic } \\
\text { Boston } \\
\text { Johns Hopkins } \\
\text { Iowa } \\
\text { Johns Hopkins } \\
\text { Chicago } \\
\text { Mayo Clinic } \\
\text { Guy's Hospital } \\
\text { Sheffield } \\
\text { Johns Hopkins } \\
\text { New Haven }\end{array}$ & $\begin{array}{r}1,000 \\
2,000 \\
500 \\
151 \\
163 \\
100 \\
500 \\
1,297 \\
146 \\
935 \\
50\end{array}$ & $\begin{array}{l}27 \\
36 \\
23 \\
20 \\
49 \\
27 \\
12 \\
16 \\
17 \\
21 \\
\\
52\end{array}$ \\
\hline & & $\begin{array}{l}\text { Total } \\
\mathbf{6 , 8 4 2}\end{array}$ & $\begin{array}{c}\text { Mean } \\
27.3\end{array}$ \\
\hline
\end{tabular}

These figures refer to patients whose illness was considered entirely psychiatric. Patients with concurrent organic and psychiatric illness account for another 10 to $40 \%$ of the patients seen in the different surveys.
Surgical out-patients have not been studied to a similar extent though Zwerling, Titchener, Gottschalk, Levine, Culbertson, Cohen and Silver (1955) considered that the mental health of only I in 10 of 200 surgical patients was satisfactory. Bryson (1945) reported on 2,320 gynæcological patients: 348 were thought to have a functional illness; 932 an organic illness; and 1,040 had abnormalities in both fields of study. Thus $59.8 \%$ of the patients needed some psychiatric understanding. Morris and O'Neil (1958) saw 60 women attending a gynæcological clinic. They concluded 'that emotional tensions outweighed physical malfunction and disease as a cause of illness in the patients seen'.

Consideration of these papers supports the conclusion of a B.M.A. Committee (I94I) which stated 'that in any group of sick people something like $30 \%$ will be found to be suffering from conditions about which it is helpful to have psychiatric advice'. Such psychiatric advice has not, until recently, been readily available at general hospitals. It is not surprising to find that little information is given in the above papers (mostly written by physicians) as to the type of psychiatric illness seen, the social problems presented by the patients, the treatment needed and the outcome of the illness. It was in an attempt to answer some of these questions that the investigation described here was carried out. (Culpan and Davies, 1960).

\section{Investigation}

While acting as a psychiatric registrar at a general non-teaching hospital, it was possible for me to see a number of new referrals to the general out-patient clinics. At the medical clinics, after the physician had seen each new patient, he told him that he wanted another doctor to see him, but it was not mentioned that I was a psychiatrist. The patient was then seen for 20 to 30 -minutes and after some questions about presenting symptoms, an attempt was made to get him talking about various aspects of his life. The presence or absence of psychiatric symptoms was noted. With the physician's findings available a 
diagnosis was made of organic illness only, psychiatric illness only, or a mixed syndrome.

One hundred consecutive new referrals to the medical out-patient clinics were seen in this way. Table 2 shows the incidence of psychiatric illness in these patients.

TABLE 2

InCidence of Psychiatric Illness in IOO Consecutive New Referrals to a Medical Out-patient Clinic

\begin{tabular}{|c|c|c|c|c|}
\hline $\begin{array}{l}\text { No. of } \\
\text { Patients }\end{array}$ & Organic & Mixed & Psychiatric & $\begin{array}{c}\text { Not } \\
\text { Diagnosed }\end{array}$ \\
\hline 100 & 43 & 13 & 38 & 6 \\
\hline
\end{tabular}

Later the patients with psychiatric and psychosomatic illness were seen for further interviews so that they could be studied in more detail.

A similar survey by Culpan of 100 new referrals to the surgical out-patient clinics at the same hospital gave the incidence of psychiatric illness only as $5 \%$ (Table 3$)$.

\section{TABle 3}

InCidence OF PSychiatric Illness in IOO New Referrals to a Slrgical Ott-Patient Clinic

\begin{tabular}{c|c|c|c|c}
\hline $\begin{array}{c}\text { No. of } \\
\text { Patients }\end{array}$ & Organic & Mixed & Psychiatric & $\begin{array}{c}\text { Not } \\
\text { Diagnosed }\end{array}$ \\
\hline 100 & 66 & 16 & 5 & 13 \\
\hline
\end{tabular}

Patients with psychosomatic diseases (peptic ulceration, thyrotoxicosis, etc.) were classified as organic if no formal psychiatric conditions were present ( 24 at both clinics) while seven others were allocated to the mixed diagnostic group.

As expected, the commonest symptoms seen in these patients were anxiety and depression, symptoms associated with an affective disorder. In the medical patients $5 \mathrm{I}$ of the 100 patients had psychiatric symptoms and in 37 of these the diagnosis was an affective disorder. In 17 of these depression was the main feature of the illness. Many papers have recently drawn attention to the importance of recognizing and treating patients with a depressive illness. Ziegler (1939) described I I I depressed patients who went first to a surgeon or physician for the relief of bodily symptoms. 'These patients', he writes, 'were grossly and universally misunderstood. Depression was not usually the first manifestation of the disorder. There was, first, fatigue, loss of appetite, weight loss and sleeplessness. Depression, anxious concern about self, shame and melancholy came later. In addition, unusual bodily sensations occurred, often leading the patient from doctor to doctor in vain attempts to locate the trouble with laboratory tests'.

At interview, information was obtained from the patients concerning current social difficulties. No objective assessment of these was possilate but Table 4 shows the incidence of these among the medical out-patients.

TABLE 4

InCidence of Social Difficulties RePorted By Medical Out-Patients

\begin{tabular}{|c|c|c|c|c|}
\hline & \multicolumn{2}{|c|}{ Organic Illness } & \multicolumn{2}{|c|}{ Psychiatric Illns } \\
\hline & Men & Women & Men & Womér \\
\hline $\begin{array}{l}\text { Per cent. re- } \\
\text { porting social } \\
\text { difficulties } .\end{array}$ & 12.5 & 26.2 & 76.9 & 60.0 \\
\hline
\end{tabular}

As will be seen, social problems are frequenty reported by the patients with a psychiatric illnegs. Like Pemberton (I95I) it was found that some disturbance of interpersonal relationship in the family circle was the commonest difficulty but death or severe illness of the spouse or near relatide was also frequent.

What kind of treatment did these patients with a psychiatric illness appear to need? Only roy personal opinion can be given. Of the $5^{\mathrm{I}}$ patierats at the medical clinic with a psychiatric illness, $\overline{\mathbf{F}}_{4}$ needed a full physical examination, reassurfonee about the absence of organic illness ans explanation about the relationship between andety and symptoms: I9 patients appeared to heogd supportive treatment-i.e. regular, brief tales with an interested doctor and perhaps mid sedative or stimulant drugs; in other words, family doctor treatment: I 8 of the patients appeared to need more complex psychiata treatment than the general practitioner could be expected to provide. Among the surgical patiens, Io appeared to need additional psychiatric help.

A short term follow-up was possible on the patients at the medical clinic with a psychiatejc illness. Between three and six months of their first attendance $52 \%$ of these patients hid improved and were virtually free from symptoms. A longer follow-up was not possible in the present study.

Macy and Allen (1933) draw attention to the surgical hazards of a neurotic illness. The followed for six years 235 patients diagnosed ot the Mayo Clinic as having a neurotic illness. They found that 200 of these 235 patients had had 280 separate operations (particularly tonsillectom and gynæcological operations). In the majority $\oint_{\mathrm{g}}$ cases these operations did not relieve the sym toms they were designed to cure.

\section{Discussion}

The review of the literature and the investigation described show the importance of psychiatic 
TABLE 5

Comparison between Means for Total C.M.I. Scores

\begin{tabular}{|c|c|c|c|c|c|c|c|c|}
\hline Groups & & & & Number & $\begin{array}{c}\text { Mean } \\
\text { Scores }\end{array}$ & $\begin{array}{c}\text { Difference } \\
\text { between } \\
\text { Means }\end{array}$ & t. & P. \\
\hline $\begin{array}{l}\text { (A) FEMALES } \\
\text { Neurotic control group } \\
\text { (a) Normal control group . }\end{array}$ & $\begin{array}{l}\cdots \\
\ldots\end{array}$ & $\begin{array}{l}\cdots \\
\cdots\end{array}$ & $\begin{array}{l}\cdots \\
\cdots\end{array}$ & $\begin{array}{l}72 \\
56\end{array}$ & $\begin{array}{l}45.6 \\
20.8\end{array}$ & 24.8 & 7.1 & $<0.001 *$ \\
\hline $\begin{array}{l}\text { 'Organic' medical patients } \\
\text { 'Psychiatric' medical patients }\end{array}$ & $\cdots$ & $\cdots$ & $\cdots$ & 22 & $\begin{array}{l}21.0 \\
40.2\end{array}$ & 19.2 & 3.40 & $<0.01 *$ \\
\hline $\begin{array}{l}\text { Neurotic control group } \\
\text { (c) } P \text { sychiatric' medical patients }\end{array}$ & & $\begin{array}{l}\cdots \\
\cdots\end{array}$ & $\begin{array}{l}\cdots \\
\cdots\end{array}$ & $\begin{array}{l}72 \\
24\end{array}$ & $\begin{array}{l}45.6 \\
40.2\end{array}$ & 5.4 & 0.98 & $>0.05$ \\
\hline $\begin{array}{l}\text { (B) MALES } \\
\text { Neurotic control group } \\
\text { (a) Normal control group. . }\end{array}$ & $\begin{array}{l}\cdots \\
\cdots\end{array}$ & $\begin{array}{l}\cdots \\
\cdots\end{array}$ & $\begin{array}{l}\cdots \\
\cdots\end{array}$ & $\begin{array}{r}46 \\
48\end{array}$ & $\begin{array}{l}32.5 \\
\text { I I.0 }\end{array}$ & $21 \cdot 5$ & $7 \cdot 55$ & $<0.001^{*}$ \\
\hline $\begin{array}{l}\text { 'Organic' medical patients } \\
\text { 'Psychiatric' medical patients }\end{array}$ & $\cdots$ & $\begin{array}{l}\cdots \\
\cdots\end{array}$ & $\cdots$ & $\begin{array}{l}19 \\
13\end{array}$ & $\begin{array}{l}14.7 \\
29.1\end{array}$ & 14.4 & 2.90 & $<0.01 *$ \\
\hline $\begin{array}{l}\text { Neurotic control group } \\
\text { (c) 'Psychiatric' medical patients }\end{array}$ & $\cdots$ & $\begin{array}{l}\cdots \\
\cdots\end{array}$ & $\begin{array}{l}\cdots \\
\ldots\end{array}$ & $\begin{array}{l}46 \\
13\end{array}$ & $\begin{array}{l}32.5 \\
29.1\end{array}$ & 3.4 & 0.59 & $>0.05$ \\
\hline
\end{tabular}

* Significant at $5 \%$ level.

illness at the general out-patient clinic. 'These patients form only a small part of the problem of psychiatric illness as it presents to the family doctor. Most of these patients he diagnoses correctly and treats himself, while a few he will refer to psychiatrists. Patients seen here were referred to 'exclude' organic disease. Of the $3^{8}$ patients at the medical clinic with a psychiatric illness, only 16 of the referring letters mentioned that the patient was anxious or under stress, but in addition most of the 16 letters suggested the presence of organic disease as well. The problem of which patient the family doctor refers to a psychiatrist and which patients he should refer has recently been discussed by Kessel (1963). He comments that referral of neurotic patients should depend on clinical severity of the symptoms and failure to respond to treatment rather than niceties of diagnosis or length of history.

From the point of view of the specialist who sees these patients, his main function appears to be to exclude the presence of organic disease. Today diagnosis is the keyword in clinical medicine and diseases are being investigated by more and more elaborate techniques. It is very easy to forget the patient as a person with his own emotional and social problems among the technicalities of modern medicine in a busy out-patient setting.
'I'he implications of this sort of study are that the family doctor and specialist should be able to recognize, investigate and treat these patients with relatively mild psychiatric illnesses. It is particularly important that undergraduates should not learn from specialists to be unsympathetic to psychiatric patients and their symptoms.

\section{The Cornell Medical Index Health Questionnaire: (C.M.I.)}

The clinical investigation described above was an appropriate setting in which to test the value of the above medical questionnaire. As the results showed that the questionnaire is a useful tool in detecting the neurotic patient, its use will be described, though a full statistical analysis of the results has been published elsewhere(Culpan, Davies and Oppenheim, r960).

The C.M.I. is a four-page self-administered inventory of 195 questions. These questions are phrased in informal language and to each question the patient answers 'Yes' or 'No'. The questions correspond closely to those usually asked at a comprehensive medical interview. There are two forms of the questionnaire, one for women, one for men, identical except for six questions on genito-urinary symptoms. The development of the C.M.I. is described by Brodman, Erdman, Large, Wolff and Broadbent (1949). It was 
intended to obtain the facts of a medical history and to serve as an adjunct to the interview. The questionnaire is divided into 18 sections. The first 12 sections deal with individual bodily symptoms; e.g. respiratory systems, digestive tract, skin, etc. The last six sections deal with mood and feeling patterns. With a completed questionnaire a cardiologist, for example, need not ask unnecessary questions about the nervous system or skin unless the answers indicate positive symptoms in this field. Similarly, a psychiatrist need not enquire into bodily symptoms if the answers to these questions on the questionnaire show that no symptoms are complained of.

The questionnaire takes patients 10 to 20 minutes to complete and as a rule, they find it a welcome task while waiting for the doctor. The completed forms can be 'read' very rapidly and 'Yes' responses noted.

In the present investigation all patients seen completed the questionnaire and the scores were compared statistically with scores obtained from a group of 104 psychiatric patients at the Maudsley Hospital and a group of 118 normal controls working at a large London store. Total 'Yes' responses to the questionnaire or to a particular section or sections of the questionnaire can be used in the statistical evaluation of the scores. Women record more 'Yes' responses than men so that the sexes have to be assessed separately statistical purposes.

Table 5 shows the total scores and number of subjects in the neurotic and normal control groups, and the patients at the medical out-pationt clinics separated on clinical grounds into 'orgari்' and 'psychiatric'. It will be seen that the contwol groups show a highly significant difference in the number of 'Yes' responses made to the questiog naire. The 'normal' women give on average $\mathrm{m}$ 'Yes' responses as compared with the 'neurotic' women's 46 .

Similar significant differences were seen at tae medical clinic when the organic and psychiatisc groups were compared, the latter giving twicegs many 'Yes' responses as the former.

These findings confirm the previous reports $\frac{\vec{\theta}}{\ddot{\theta}}$ the Cornell Medical Index and despite a clinioal bias against such questionnaires, it might prove of value in detecting psychiatric patients ch general practice or at the general hospital clinios.

\section{Conclusion}

Psychiatric illness presents diagnostic a⿳亠㐅冋่d therapeutic problems at general hospital clinies. These illnesses and the problems they present deserve further consideration by family doeto and specialists.

\section{REFERENCES}

Allan, F. N., and Kaufman, N. (1948): 'Nervous Factors in General Practice', f. Amer. med. Ass., I38, I135.

B.M.A. (I94I): Report of a Committee on Mental Health, London.

Brodman, K., Erdman, A. J., Large, I., Wolff, H. G., and Broadbent, T. H. (I949): The Cornell Medical Ind尽: An Adjunct to Medical Interview, $\mathcal{F}$. Amer. med. Ass., 140, 530.

Bryson, E. (1945): The Psychosomatic Approach in Gynæcological Practice, Practitioner, 155, 378.

Buck, R. W. (1930): Bull. Mass. Soc. Ment. Hyg., 60, 2.

Culpan, R., and Davies, B. (1960): Psychiatric Illness at a Medical and a Surgical Out-patient Clinic, Comprehe्wss. Psychiat., $\mathbf{1}, 228$. $-\frac{1}{\text { of the Cornell Medical Index, Brit. med. } \mathcal{F} ., \text { i, } 855}$.

Hamman, L. (1939): The Relationship of Psychiatry to Internal Medicine, Ment. Hyg. (N.Y.), $23,177$.

Kessel, N. (1963): Who Ought to See a Psychiatrist, Lancet, i, 1092.

Lewis, B. I. (I952): Psychosomatic Disorders and the Non-psychiatrist, f. Amer. med. Ass., r50, 776.

McLean, F. C. (1932): Psychiatry and General Medicine, Ment. Hyg. (N.Y.), 16, 577.

MACY, J. W., and AllEN, E. V. (1933): A Justification of the Diagnosis of Chronic Nervous Exhaustion, Ann. intern. Met., $7,86 \mathrm{r}$.

Moersch, F. P. (1 932): Psychiatry in Medicine, Amer. F. Psychiat., Ir, 83 I.

MorRIS, N., and O'NeILl, D. (1958): Out-patient Gynæcology, Brit. med. $\mathscr{J}$., i, 1038.

Pearson, R. S. B. (1938): Psychoneurosis in Hospital Practice, Lancet, i, $45 \mathrm{I}$.

Pemberton, J. (I95 I): A Sociomedical Study of 200 Hospital Medical Patients, Ibid., i, 224.

ReYNolds, G. P. (1930): The Etiology of Psychoneurosis Encountered in the Practice of Internal Medicine, Nean Engl. F. Med., 203, 312.

Roberts, B. H., and Norton, N. M. (1952) : The Prevalence of Psychiatric Illness in a Medical Out-patient Clinich, Ibid., 246, 82 .

Ziegler, L. H. (1939): Depression as Chief Symptom, Psychiat. Quart., r3, 689.

Zwerling, I., Titchener, J., GotTschalk, L., Levine, M., Culbertson, W., Cohen, S., and Silver, H. (I955) Personality Disorder and the Relationships of Emotion to Surgical Illness in 200 Surgical Patients, Amer. Psychiat., 112, 270. 